\title{
Jurnal Ilmu Kehutanan
}

\author{
Journal of Forest Science
}

https://jurnal.ugm.ac.id/jikfkt

\section{Penggunaan Principal Component Analysis dalam Distribusi Spasial Vegetasi Mangrove di Pantai Utara Pemalang}

Usage of Principal Component Analysis in the Spatial Distribution of Mangrove Vegetation in North Coast of Pemalang

Erny Poedjirahajoe*, Djoko Marsono, \& Frita Kusuma Wardhani

Departemen Konservasi Sumberdaya Hutan, Fakultas Kehutanan, Universitas Gadjah Mada, Jl. Agro No.1, Bulaksumur, Sleman 55281

${ }^{*}$ E-mail : er_pjr@yahoo.co.id

\section{HASIL PENELITIAN}

Riwayat naskah:

Naskah masuk (received): 15 Maret 2016

Diterima (accepted): 8 Nopember 2016

\section{KEYWORDS}

spatial distribution

mangrove

habitat

PCA

Pemalang

\section{KATA KUNCI}

distribusi spasial mangrove

habitat

PCA

Pemalang

\begin{abstract}
Habitat factors greatly affect the composition of the mangrove ecosystem. Changes in habitat quality may result on a shift of the type of plant mangrove ecosystem composition. This study aimed to determine the spatial distribution patterns of mangrove vegetation based on the characteristics of the habitat in the mangrove area in Pemalang District. The method used for data collection was the combination of transect method and plot sampling. The results showed that the spatial distribution of mangrove habitat factors at each observation station formed three clusters with different characteristics. Cluster 1 was characterized by low levels of $\mathrm{pH}$, dissolved oxygen, and temperatures, as well as high values of mud thickness, and salinity. Cluster 2 was characterized by the low amount of dissolved oxygen, salinity, and mud thickness and high levels of temperature and $\mathrm{pH}$. Cluster 3 was characterized by low values of $\mathrm{pH}$, salinity, and mud thickness but high amount of dissolved oxygen and mild temperatures. The spatial distribution of mangrove species based on the characteristics of the habitat factors formed three clusters. Cluster 1 were Rhizophora mucronata Lam. and Sonneratia alba Sm. species as the habitat characteristics were mild temperatures and high amount of dissolved oxygen. Cluster 2 were Acanthus ilicifolius L., Avicennia alba Blume, and Rhizophora apiculata Blume with habitat characteristics were moderate levels of mud thickness, $\mathrm{pH}$, dissolved oxygen and salinity. Cluster 3 was Avicennia marina (Forsk.) Vierh. as its habitat characteristics were high values of $\mathrm{pH}$, salinity, temperature, and mud thickness.
\end{abstract}

\section{INTISARI}

Habitat sangat memengaruhi komposisi penyusun ekosistem mangrove. Perubahan kualitas habitat secara kompleks dapat mengakibatkan pergeseran jenis tanaman penyusunnya. Penelitian ini bertujuan untuk mengetahui pola distribusi spasial vegetasi mangrove berdasarkan karakteristik habitat di kawasan rehabilitasi mangrove Pemalang. Metode 
yang digunakan adalah kombinasi antara metode jalur dan petak contoh. Hasil penelitian menunjukkan sebaran spasial faktor habitat mangrove pada setiap stasiun pengamatan membentuk tiga cluster dengan karakteristik yang berbeda. Cluster 1 dicirikan $\mathrm{pH}$, oksigen terlarut, dan suhu yang rendah, ketebalan lumpur dan salinitas yang tinggi. Cluster 2 oleh kandungan oksigen terlarut, salinitas, dan tebal lumpur yang rendah, serta suhu dan $\mathrm{pH}$ yang tinggi. Cluster 3 dengan $\mathrm{pH}$, salinitas, dan tebal lumpur yang rendah serta kandungan oksigen terlarut yang tinggi dan suhu yang sedang. Sebaran spasial jenis mangrove berdasarkan karakteristik faktor habitat dapat membentuk tiga cluster. Cluster 1 terdiri dari Rhizophora mucronata Lam. dan Sonneratia alba Sm. dengan karakteristik habitat berupa suhu yang sedang dan oksigen terlarut yang tinggi. Cluster 2 terdiri dari Acanthus ilicifolius L., Avicennia alba Blume, dan $R$. apiculata Blume dengan karakteristik habitat berupa tebal lumpur, $\mathrm{pH}$, oksigen terlarut, dan salinitas yang sedang. Cluster 3 dengan jenis Avicennia marina (Forsk.) Vierh. dengan karakteristik habitat berupa $\mathrm{pH}$, salinitas, suhu, dan tebal lumpur yang tinggi.

(ㄷ) Jurnal Ilmu Kehutanan Allright reserved

\section{Pendahuluan}

Hutan mangrove merupakan sumber daya alam tropis yang mempunyai manfaat ganda, baik dari aspek sosial, ekonomi, maupun ekologi. Berbeda dengan hutan daratan, hutan mangrove memiliki habitat yang lebih spesifik karena adanya interaksi antara komponen penyusun ekosistem yang kompleks dan rumit. Komponen penyusun ekosistem tersebut saling berinteraksi membentuk suatu kesatuan yang utuh dan tidak dapat berdiri sendiri. Hutan mangrove termasuk tipe ekosistem yang tidak terpengaruh oleh iklim, tetapi faktor edafis sangat dominan dalam pembentukan ekosistem ini (Indriyanto 2006).

Habitat merupakan faktor yang penting dalam pertumbuhan, perkembangbiakan, dan penentu keberhasilan dalam kegiatan rehabilitasi dan pengelolaan mangrove. Poedjirahajoe (2010) menyatakan bahwa, faktor habitat sangat berpengaruh terhadap komposisi penyusun ekosistem mangrove bahkan perubahan kualitas habitat secara kompleks dapat mengakibatkan pergeseran jenis vegetasi penyusunnya. Jenis vegetasi yang mampu beradaptasi pada kondisi habitat yang mengalami perubahan dikhawatirkan dapat mendominasi kawasan tersebut sehingga menyebabkan terjadinya penurunan keanekaragaman jenis di dalam kawasan.

Dalam pengelolaan kawasan mangrove perlu diketahui kondisi ekologis habitat yang sesuai dengan jenis tanaman yang akan dikembangkan. Faktor habitat yang memengaruhi vegetasi mangrove bersifat kompleks sehingga diperlukan penyederhanaan faktor habitat dengan cara klasifikasi atau pengelompokan habitat. Pengelompokan habitat merupakan salah satu cara yang dianggap tepat untuk menunjukkan pengaruh faktor lingkungan terhadap pertumbuhan vegetasi mangrove (Poedjirahajoe 2006). Model pengelompokan membantu untuk menunjukkan dominansi atau kedekatan hubungan masing-masing faktor yang berpengaruh terhadap pertumbuhan vegetasi.

Pengelompokan tersebut juga berguna untuk mengetahui kesamaan faktor pengendali pertumbuhan mangrove pada suatu wilayah dengan wilayah lainnya. Hal ini akan memudahkan pengelola untuk mengetahui karakteristik habitat pada masingmasing wilayah sehingga dapat diketahui model pengelolaan yang efektif dan sesuai dengan kondisi ekologis kawasan serta bermanfaat dalam optimalisasi pertumbuhan mangrove dan meminimalisir 
kegagalan pengelolaan. Tujuan dari penelitian ini adalah untuk mengetahui karakteristik habitat mangrove pada setiap stasiun pengamatan dan mengetahui pola sebaran spasial jenis mangrove berdasarkan karakteristik faktor habitat. Penelitian ini diharapkan dapat memberikan gambaran mengenai pola pengelompokan vegetasi mangrove di kawasan tersebut dan faktor-faktor lingkungan yang memengaruhi pola pengelompokannya.

\section{Bahan \& Metode}

\section{Lokasi penelitian}

Penelitian ini dilakukan di kawasan rehabilitasi mangrove di Desa Mojo, Kecamatan Ulujami, Kabupaten Pemalang. Pada kawasan tersebut ditempatkan tiga stasiun pengamatan dengan luas total kawasan \pm 117 ha. Stasiun pengamatan pertama terletak pada bagian utara sedangkan stasiun ketiga terletak di dekat area pertambakan milik masyarakat dan stasiun kedua terletak di antara stasiun pertama dan stasiun ketiga.

\section{Pengumpulan data}

Metode yang digunakan adalah kombinasi antara metode jalur dan petak contoh. Jalur dibuat tegak lurus garis pantai karena metode ini lebih efektif untuk mengetahui perubahan kondisi vegetasi menuju ke arah pantai. Pada setiap stasiun pengamatan ditempatkan empat jalur pengamatan. Setiap jalur dibagi menjadi tiga zona, yaitu zona 1 (proksimal), 2 (medial), dan 3 (distal) yang masingmasing ditempatkan 1 petak ukur (PU). Jarak antar PU disesuaikan dengan ketebalan mangrove di tiap transeknya. Semakin tebal mangrove maka jarak antar PU akan semakin panjang dan sebaliknya. Jarak antar jalur pengamatan disesuaikan dengan panjang kawasan mangrove. Semakin panjang kawasan maka jarak antar jalur semakin lebar.

Desain penempatan PU dapat dilihat pada Gambar 1. Petak ukur yang digunakan berbentuk persegi yang dibuat secara bertingkat/bersarang (nested sampling) untuk mengetahui kondisi vegetasi pada masing-masing tingkat pertumbuhan. Besarnya intensitas sampling dalam penelitian ini yaitu o,o1 untuk semai; 0,06 untuk pancang; dan 0,26 untuk pohon. Contoh nested sampling yang digunakan dalam pengambilan data dapat dilihat pada Gambar 2.

Data vegetasi yang diambil berupa jenis tumbuhan yang terdapat di dalam PU. Untuk tingkat pertumbuhan pancang dan pohon diukur tinggi dan diameter sedangkan untuk tingkat pertumbuhan semai hanya didata jenis dan jumlahnya. Kriteria tingkat pertumbuhan mangrove berdasarkan Surat Keputusan Direktorat Jenderal Kehutanan No. 6o/Kpts/DI/1978 tentang Pedoman Sistem Silvikultur Hutan Payau, yaitu:

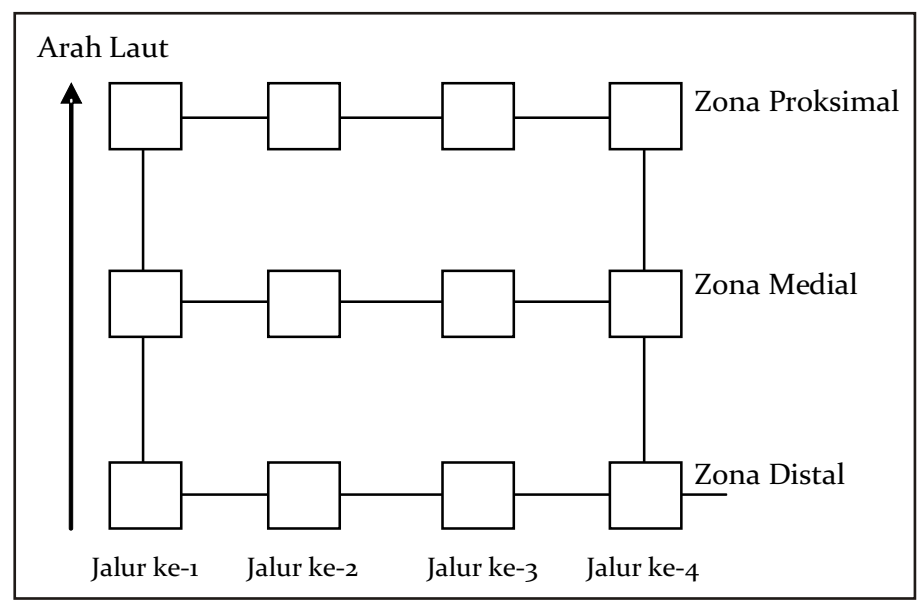

Gambar 1. Desain penempatan petak ukur Figure 1. Placement design of sampling units

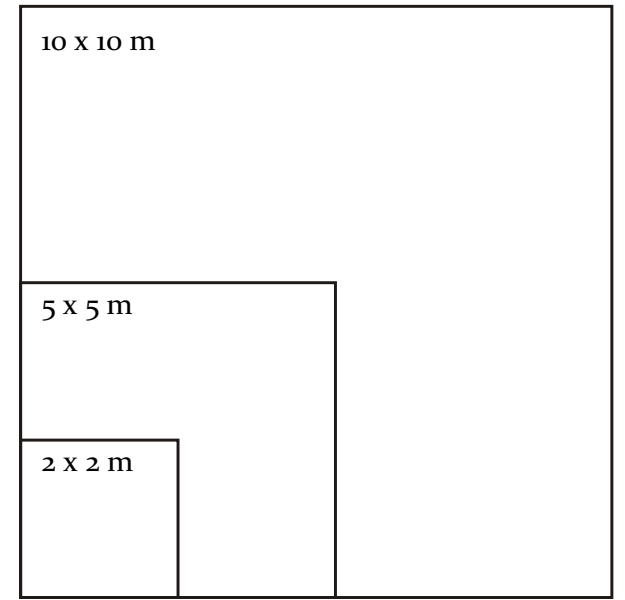

Gambar 2. Pola nested sampling Figure 2. Nested sampling pattern 
a. Semai (seedling), anakan sampai tumbuhan yang tingginya kurang dari 1,5 $\mathrm{m}$ (ukuran petak 2 x $2 \mathrm{~m}$ ).

b. Pancang (sapling), tumbuhan yang tingginya lebih dari $1,5 \mathrm{~m}$ dan berdiameter kurang dari $10 \mathrm{~cm}$ (ukuran petak $5 \times 5 \mathrm{~m}$ ).

c. Pohon (tree), tumbuhan yang berdiameter lebih dari $10 \mathrm{~cm}$ (ukuran petak $10 \mathrm{x} 10 \mathrm{~m}$ ).

Selain data vegetasi, pada setiap PU juga dilakukan pengukuran kualitas fisik dan kimia habitat, meliputi suhu, pH, salinitas, kandungan oksigen terlarut, dan ketebalan lumpur. Suhu air diukur dengan menggunakan thermometer stick, $\mathrm{pH}$ menggunakan $\mathrm{pH}$ meter, salinitas menggunakan Salt Test Digital. Pengukuran oksigen terlarut menggunakan Oxymeter dan ketebalan lumpur menggunakan galah berskala yang ditancapkan pada beberapa titik.

\section{Analisis data}

Data kualitas habitat baik fisik dan kimia yang telah diukur, dirata-rata dan kemudian disajikan dalam bentuk grafik hubungan antara kualitas fisik dan kimia habitat dengan stasiun pengamatan sehingga dapat diketahui pola perubahan/perbedaan kualitas fisik dan kimia pada tiap stasiun pengamatan. Kualitas fisik dan kimia sebagai sumbu (y) sedangkan stasiun pengamatan sebagai sumbu (x). Selanjutnya, untuk menentukan sebaran spasial karakteristik fisik kimia perairan antar stasiun pengamatan menggunakan pendekatan statistik multivariabel yang didasarkan pada Analisis Komponen Utama (Principal Component Analysis/PCA). Matriks data yang ditampilkan terdiri dari stasiun pengamatan sebagai variabel individu (baris) dan parameter kualitas air sebagai variabel kuantitatif (kolom). Principal Component Analysis pada prinsipnya menggunakan pengukuran jarak euclidean pada data. Semakin kecil jarak euclidean antara dua stasiun, maka semakin mirip karakteristik parameter lingkungan tersebut. Jarak euclidiean didasarkan pada rumus sebagai berikut (Bengen 2000):

$$
d^{2}\left(i, i^{\prime}\right)=\sum_{j=1}^{p}\left(X_{i j}-X_{i^{\prime} j}\right)^{2}
$$

Hasil akhir analisis komponen utama yaitu ada tidaknya perbedaan sebaran spasial parameter fisik dan kimia perairan di antara berbagai titik pengamatan. Principal Component Analysis ini menggunakan software Xlstat versi 5.o.

Analisis vegetasi mangrove di kawasan tersebut dihitung kemelimpahan tumbuhan mangrove berdasarkan Indeks Nilai Penting dan keanekaragaman jenis menggunakan Indeks Diversitas Shannon. Pola distribusi spasial vegetasi mangrove dianalisis dengan menggunakan pendekatan analisis multivariat PCA. Penggunaan metode ini bertujuan untuk menentukan pola sebaran jenis tanaman mangrove dan faktor habitat yang memengaruhi pola sebaran tersebut. Software yang digunakan untuk analisis PCA adalah Xlstat versi 5.0.

\section{Hasil \& Pembahasan}

\section{Karakteristik habitat}

Berdasarkan hasil penelitian, kualitas fisik dan kimia habitat mangrove Desa Mojo dapat dilihat pada Gambar 3. Rata-rata pH baik pada stasiun 1, 2, dan 3 berkisar antara 6,98-7,48. Hal tersebut menunjukkan bahwa $\mathrm{pH}$ perairan masih berada pada kisaran baik bagi vegetasi mangrove dan biota perairan. Menurut Koch (2001), pH berhubungan erat dengan aktivitas dekomposer. Pada $\mathrm{pH}$ asam aktivitas dekomposer sangat rendah sehingga perombakan bahan organik menjadi anorganik menjadi lamban. Lambannya proses dekomposisi sangat menghambat pertumbuhan vegetasi karena kurangnya pasokan hara dan mineral. Selain itu, nilai pH 6,o-6,5 dapat menurunkan keanekaragaman jenis plankton dan bentos (Effendi 2003).

Rata-rata terendah kandungan oksigen terlarut yaitu pada stasiun 1 sebesar $6,54 \mathrm{mg} / \mathrm{l}$ sedangkan tertinggi pada stasiun 2 sebesar 7,32 mg/l. Rendahnya oksigen terlarut terutama pada kawasan mangrove 


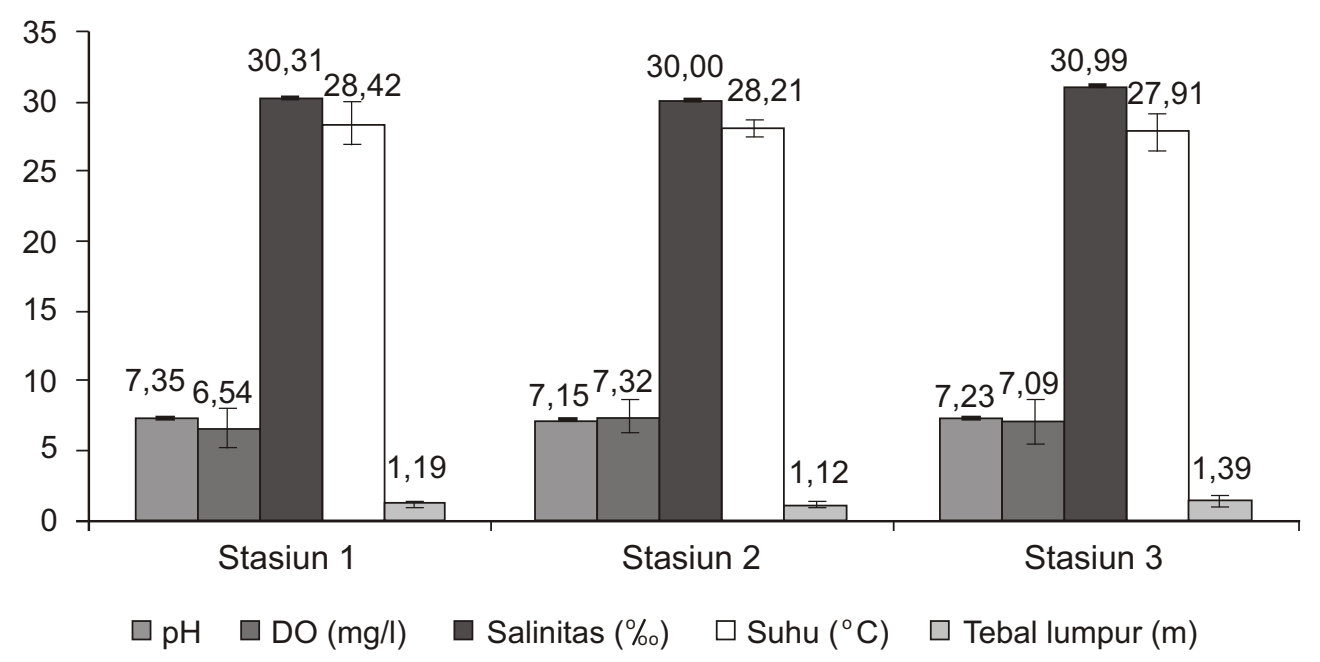

Gambar 3. Kualitas fisik dan kimia habitat mangrove di Desa Mojo

Figure 3. Physical and chemical qualities of mangrove habitat in Mojo Village

stasiun 1 kemungkinan disebabkan oleh aktivitas fotosintesis fitoplankton yang tidak maksimal. Karena kekeruhan yang tinggi, hal ini juga berpengaruh sehingga aktivitas fotosintesis terganggu mengingat pengambilan data dilakukan saat kondisi pasang dengan kondisi perairan yang keruh. Selain itu, suhu air yang terlalu tinggi dapat meningkatkan kecepatan metabolisme biota air dan meningkatkan respirasi biota perairan sehingga dapat menurunkan jumlah oksigen yang terlarut dalam air.

Septiarusli (2006) menyebutkan bahwa mangrove dapat tumbuh dengan baik pada salinitas air payau antara 2 - 22\%o atau air asin dengan salinitas mencapai 38\%o. Pada stasiun 1, 2, dan 3 memiliki nilai salinitas rata-rata yang tergolong baik berkisar antara 30-30,99\%o. Meskipun menunjukkan nilai yang cukup tinggi tetapi salinitas yang terdapat di perairan tersebut masih cukup sesuai untuk tempat tumbuh mangrove.

Rata-rata suhu perairan pada stasiun 1, 2, dan 3 berkisar antara $27,91-28,42^{\circ} \mathrm{C}$. Kisaran suhu tersebut termasuk baik untuk pertumbuhan mangrove. Alongi (2009) menyatakan bahwa konduktansi stomata dan laju asimilasi pada daun mangrove yang maksimal berkisar pada suhu $25-30^{\circ} \mathrm{C}$ dan akan mengalami penurunan yang cepat pada suhu di atas $35^{\circ} \mathrm{C}$. Untuk jenis Rhizophora, proses fotosintesis paling cepat pada suhu $25^{\circ} \mathrm{C}$ dan akan menurun tajam pada suhu di atas $35^{\circ} \mathrm{C}$ (Hogarth 2007). Selain akan memengaruhi proses fisiologi tumbuhan mangrove, suhu perairan juga dapat memengaruhi kegiatan hewan air seperti migrasi, pemangsaan, kecepatan berenang, perkembangan embrio, dan kecepatan proses metabolisme (Cahyani 2001). Terdapat beberapa hal yang memengaruhi tingginya suhu, antara lain intensitas sinar matahari yang secara langsung jika kawasan mangrove agak terbuka karena jarak antar pohon agak besar.

Rata-rata ketebalan lumpur yang tertinggi terdapat pada stasiun 3 sebesar 1,39 meter, bahkan pada zona proksimal, kedalaman lumpur dapat mencapai lebih dari 2 meter. Tebal lumpur berkaitan erat dengan lama genangan dan kecepatan arus. Jika pergantian pasang surut terjadi dalam waktu yang lama dengan kecepatan arus yang minimal, maka lumpur yang terakumulasi menjadi tebal, demikian pula sebaliknya, jika pergantian pasang surut terjadi dalam waktu yang singkat serta dengan kecepatan arus yang minimal, maka lumpur yang terakumulasi menjadi semakin sedikit. Faktor lain yang dapat memengaruhi akumulasi substrat lumpur yaitu struktur dan kerapatan akar mangrove. Darmawan (2002) menyebutkan bahwa semakin bertambahnya umur tanaman dapat meningkatkan ketebalan substrat lumpur. 
Variabel fisik dan kimia habitat diseleksi dengan menggunakan PCA. Melalui analisis ini dapat dikelompokkan variabel-variabel penting untuk menduga fenomena sekaligus memahami karakteristik fisik dan kimia habitat pada setiap stasiun pengamatan. Hasil PCA disajikan pada Tabel 1 dan 2, menunjukkan bahwa pengelompokan plot pengamatan berdasarkan lima karakteristik habitat cukup dilakukan dengan menggunakan tiga faktor, yaitu faktor 1, 2, dan 3. Ketiga faktor tersebut dapat menjelaskan sebesar 80,91\% dari variasi total. Faktor utama lainnya tidak digunakan dalam klasifikasi karena mempunyai kemampuan yang cukup rendah dalam menerangkan variasi total atau lebih rendah dari kontribusi rata-rata setiap variabel terhadap varian total. Terdapat empat variabel yang memiliki pengaruh nyata terhadap variabel baru. Empat variabel tersebut dapat dirumuskan dalam tiga faktor utama yang memiliki korelasi yang cukup erat dengan variabel yang dianalisis dan dapat dianggap mencerminkan fenomena-fenomena yang terkait dengan karakteristik habitat kawasan tersebut.

Pada tabel eigenvalues dan tabel factor loadings menunjukkan bahwa faktor utama $1\left(\mathrm{~F}_{1}\right)$ merepresentasikan sekitar 36,82\% dari keragaman data dengan variabel penciri utamanya yaitu suhu (nilai factor loadings sebesar -o,8680) dan ketebalan lumpur (nilai factor loadings sebesar o,8686). Namun variabel suhu berkorelasi negatif, dimana dengan meningkatnya ketebalan lumpur di sisi lain justru dapat menurunkan suhu perairan. Seperti yang sudah dijelaskan sebelumnya bahwa, terdapat beberapa faktor yang dapat memengaruhi ketebalan lumpur yaitu lama genangan, kecepatan arus, serta struktur dan kerapatan perakaran mangrove. Struktur dan kerapatan perakaran mangrove yang cukup rapat akan mampu mengikat substrat lumpur sehingga dapat meningkatkan ketebalan lumpur. Struktur perakaran mangrove yang rapat tersebut dapat berhubungan dengan kerapatan individu jenis penyusun mangrove dan kerapatan tajuknya. Kondisi kawasan dengan tajuk yang cukup rapat akan menghalangi sinar matahari masuk sampai permukaan perairan sehingga suhu air yang berada di bawah tajuk tentu akan menjadi lebih rendah. Faktor utama 2 (F2) merepresentasikan sekitar 26,45\% dari keragaman data. Variabel pencirinya yaitu $\mathrm{pH}$ dengan nilai factor loadings sebesar -o,8311. Faktor utama 3 (F3) merepresentasikan sekitar 17,64\% dari keragaman data. Variabel pencirinya yaitu kandungan oksigen terlarut dengan nilai factor loadings sebesar o,70o8. Karena direpresentasikan dengan faktor yang berbeda, antara variabel $\mathrm{pH}$ dan kandungan oksigen terlarut, maka keduanya relatif tak ada kaitannya satu sama lain (independen).

Tabel 1. Eigenvalues faktor hasil PCA terhadap variabel fisik dan kimia habitat

Table 1. Results of eigenvalues PCA factor to physical and chemical habitat variables

\begin{tabular}{lccccc}
\hline & $\mathrm{F}_{1}$ & $\mathrm{~F}_{2}$ & $\mathrm{~F}_{3}$ & $\mathrm{~F} 4$ & \multicolumn{1}{c}{$\mathrm{F}_{5}$} \\
\hline Eigenvalue & 1,8409 & 1,3226 & 0,8821 & 0,6368 & 0,3176 \\
Variability (\%) & 36,8184 & 26,4522 & 17,6422 & 12,7358 & 6,3514 \\
Cumulative \% & 36,8184 & 63,2706 & 80,9129 & 93,6486 & 100, oooo \\
\hline
\end{tabular}

Tabel 2. Factor loading tiap faktor fisik dan kimia habitat

Table 2. Loading factors of physical and chemical habitat factors

\begin{tabular}{lccccc}
\hline \multicolumn{1}{c}{ Variabel } & $\mathrm{F}_{1}$ & $\mathrm{~F} 2$ & $\mathrm{~F}_{3}$ & $\mathrm{~F}_{4}$ & $\mathrm{~F}_{5}$ \\
\hline $\mathrm{pH}$ & $-0,1563$ & $-0,8311$ & 0,1234 & $\mathrm{0}, 5046$ & $-0,1228$ \\
Oksigen terlarut & $-0,2855$ & 0,5884 & 0,7008 & 0,2739 & $-0,0786$ \\
Salinitas & 0,4764 & $-0,4763$ & 0,5923 & $-0,4415$ & $-0,0210$ \\
Suhu & $-0,8680$ & $-0,2310$ & 0,1420 & $-0,1049$ & 0,4025 \\
Tebal lumpur & $\mathrm{o,8686}$ & 0,0743 & 0,0697 & 0,3182 & 0,3658 \\
\hline
\end{tabular}


Setelah didapatkan nilai komponen utama kemudian dilakukan analisis lanjutan menggunakan analisis kelompok (cluster analysis) dengan metode $K$-Means untuk meminimalkan keragaman di dalam kelompok dan memaksimalkan keragaman antar kelompok. Berdasarkan tiga faktor utama yang diperoleh dari analisis komponen utama didapatkan tiga kelompok besar dengan karakteristiknya masingmasing. Hasil final analisis cluster dengan iterasi sebanyak tiga kali dengan jarak minimum antar pusat cluster 5,278 disajikan pada (Tabel 3).

Pada Tabel 3 dapat diperhatikan bahwa data tersebut masih terkait dengan proses standarisasi yang mengacu pada $z$-score dengan ketentuan, yaitu nilai negatif berarti data berada di bawah rata-rata total dan nilai positif berarti data berada di atas rata-rata total. Berdasarkan tabel tersebut dapat didefinisikan bahwa cluster 1 dicirikan dengan $\mathrm{pH}$, oksigen terlarut, dan suhu yang rendah, serta ketebalan lumpur dan salinitas yang tinggi. Cluster 2 dengan kandungan oksigen terlarut, salinitas, dan tebal lumpur yang rendah, serta suhu dan $\mathrm{pH}$ yang tinggi. Cluster 3 dengan $\mathrm{pH}$, salinitas, dan tebal lumpur yang rendah serta kandungan oksigen terlarut yang tinggi dan suhu yang sedang. Sebaran spasial plot pengamatan berdasarkan karakteristik habitat dapat dilihat pada Gambar 4.

Tabel 3. Hasil akhir cluster centers

Table 3. Output of final cluster centers

\begin{tabular}{lccc}
\hline \multirow{2}{*}{ Z-score } & \multicolumn{3}{c}{ Cluster } \\
\cline { 2 - 4 } & 1 & 2 & 3 \\
\hline Zscore (pH) & $-0,1034$ & 1,0984 & $-0,6959$ \\
Zscore (Oksigen terlarut) & $-0,5485$ & $-0,3475$ & 0,7183 \\
Zscore (Salinitas) & 0,8458 & $-0,0316$ & $-0,7024$ \\
Zscore (Suhu) & $-0,7881$ & 0,7072 & 0,1703 \\
Zscore (Tebal lumpur) & 0,6936 & $-0,4815$ & $-0,2506$ \\
\hline
\end{tabular}

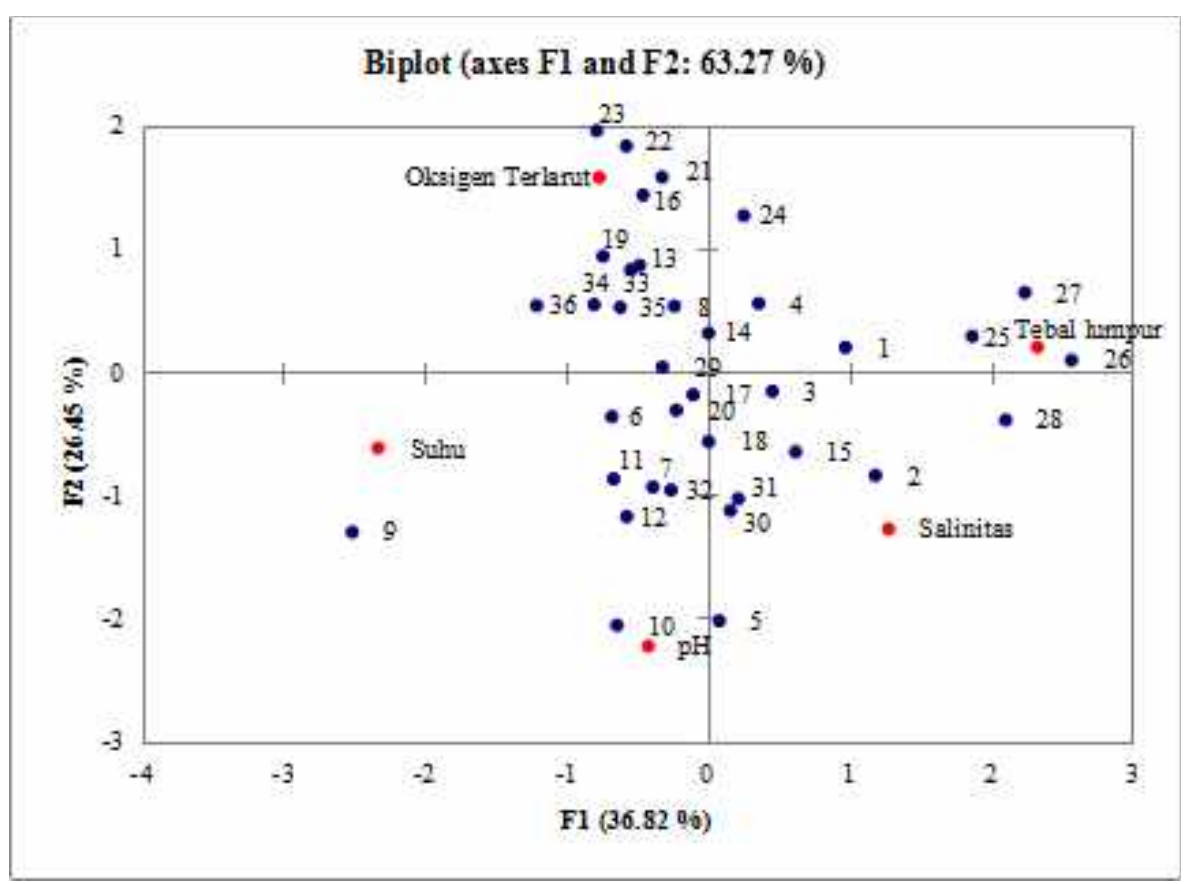

Gambar 4. Sebaran spasial plot pengamatan berdasarkan karakteristik habitat Figure 4. Spatial distribution of observation plots based on habitat characteristics 
Tahapan selanjutnya yaitu melihat perbedaan variabel pada cluster yang terbentuk. Dalam hal ini dapat dilihat dari nilai $\mathrm{F}$ dan nilai probabilitas (sig) masing-masing variabel yang disajikan pada Tabel 4 . Semakin besar nilai $\mathrm{F}$ dan signifikansi < 0,05 maka semakin besar perbedaan variabel pada cluster yang terbentuk. Berdasarkan tabel tersebut, seluruh variabel menunjukkan adanya perbedaan di antara plot pengamatan pada ketiga cluster yang terbentuk. Namun pH merupakan variabel yang paling menunjukkan adanya perbedaan.

Langkah selanjutnya adalah mengetahui jumlah anggota masing-masing cluster yang terbentuk, yaitu dengan melihat output pada Tabel 5. Berdasarkan tabel tersebut, hampir seluruh zona 1 pada setiap stasiun pengamatan masuk ke dalam cluster 1 dengan salinitas yang tinggi. Hal ini disebabkan zona 1 merupakan zona proksimal yang berhadapan langsung dengan laut sehingga salinitas di wilayah tersebut tentu lebih tinggi dibandingkan zona 2 (medial) dan 3 (distal). Sementara itu, ketebalan lumpurnya juga lebih tinggi karena letaknya yang berhadapan dengan laut sehingga mendapatkan input substrat dari arus gelombang yang masuk ke kawasan mangrove.

Stasiun pengamatan 1 zona medial dan distal masuk ke dalam cluster 2 dengan ciri suhu dan $\mathrm{pH}$ yang tinggi. Suhu yang tinggi dapat diakibatkan dari kerapatan vegetasinya, pada stasiun 1 memiliki suhu yang lebih rendah dibandingkan dua stasiun lainnya, dimana pada dua stasiun tersebut sinar matahari dapat masuk sampai permukaan perairan. Suhu yang tinggi dapat menyebabkan meningkatnya respirasi sehingga oksigen terlarut menjadi lebih rendah. Ketebalan lumpur pada cluster ini lebih tipis karena letaknya yang berada di tengah (medial) sehingga

Tabel 4. Hasil pengelompokan Anova

Table 4. Result of Anova clustering

\begin{tabular}{|c|c|c|c|c|c|c|}
\hline \multirow{2}{*}{ Variabel } & \multicolumn{2}{|c|}{ Cluster } & \multicolumn{2}{|c|}{ Error } & \multirow{2}{*}{$\mathrm{F}$} & \multirow{2}{*}{ Sig. } \\
\hline & Mean Square & $\mathrm{df}$ & Mean Square & $\mathrm{df}$ & & \\
\hline Zscore (pH) & 9,486 & 2 & 0,486 & 33 & 19,531 & 0,000 \\
\hline Zscore (Oksigen terlarut) & 6,021 & 2 & 0,696 & 33 & 8,654 & 0,001 \\
\hline Zscore (Salinitas) & $7,75^{1}$ & 2 & 0,591 & 33 & 13,119 & 0,000 \\
\hline Zscore (Suhu) & 6,430 & 2 & 0,671 & 33 & 9,584 & 0,001 \\
\hline Zscore (Tebal lumpur) & 4,486 & 2 & 0,789 & 33 & 5,687 & o,008 \\
\hline
\end{tabular}

Tabel 5. Grup tiap cluster

Table 5. Group of each cluster

\begin{tabular}{|c|c|c|c|c|c|c|c|c|}
\hline \multicolumn{3}{|c|}{ Cluster 1} & \multicolumn{3}{|c|}{ Cluster 2} & \multicolumn{3}{|c|}{ Cluster 3} \\
\hline $\begin{array}{c}\text { Stasiun } \\
\text { Pengamatan }\end{array}$ & Zona & No. PU & $\begin{array}{c}\text { Stasiun } \\
\text { Pengamatan }\end{array}$ & Zona & $\begin{array}{l}\text { No. } \\
\text { PU }\end{array}$ & $\begin{array}{c}\text { Stasiun } \\
\text { Pengamatan }\end{array}$ & Zona & $\begin{array}{l}\text { No. } \\
\text { PU }\end{array}$ \\
\hline 1 & 1 & 1 & 1 & 2 & 5 & 1 & 1 & 4 \\
\hline 1 & 1 & 2 & 1 & 2 & 6 & 1 & 2 & 8 \\
\hline 1 & 1 & 3 & 1 & 2 & 7 & 2 & 1 & 13 \\
\hline 2 & 1 & 15 & 1 & 3 & 9 & 2 & 1 & 14 \\
\hline 2 & 2 & 17 & 1 & 3 & 10 & 2 & 1 & 16 \\
\hline 2 & 2 & 18 & 1 & 3 & 11 & 2 & 2 & 19 \\
\hline 3 & 1 & 25 & 1 & 3 & 12 & 2 & 3 & 21 \\
\hline 3 & 1 & 26 & 2 & 2 & 20 & 2 & 3 & 22 \\
\hline 3 & 1 & 27 & 3 & 2 & 29 & 2 & 3 & 23 \\
\hline 3 & 1 & 28 & 3 & 2 & 32 & 2 & 3 & 24 \\
\hline 3 & 2 & 30 & & & & 3 & 3 & 33 \\
\hline \multirow[t]{3}{*}{3} & 2 & 31 & & & & 3 & 3 & 34 \\
\hline & & & & & & 3 & 3 & 35 \\
\hline & & & & & & 3 & 3 & 36 \\
\hline
\end{tabular}


pasokan substrat yang diperoleh baik dari laut maupun sungai tidak dapat secara langsung sampai ke kawasan ini.

Stasiun pengamatan 2 paling banyak masuk pada cluster 3 dengan ciri oksigen terlarut yang tinggi dan suhu yang sedang. Suhu yang relatif sedang disebabkan karena kerapatan vegetasi di stasiun pengamatan 2 yang cukup rapat. Kandungan oksigen terlarut yang tinggi menandakan proses fotosintesis oleh fitoplankton di kawasan tersebut cukup optimal. Selain itu, cluster 3 dicirikan dengan salinitas yang rendah karena letaknya yang lebih dekat ke arah daratan sehingga salinitasnya tergolong payau.

\section{Distribusi spasial vegetasi berdasarkan karakteristik habitat}

Avicennia alba, Avicennia marina, dan Rhizophora mucronata merupakan jenis yang banyak ditemukan pada setiap stasiun pengamatan. Hal ini disebabkan ketiga jenis tanaman tersebut merupakan jenis-jenis yang ditanam dan mampu beradaptasi dengan baik pada kondisi habitat di kawasan mangrove Mojo. Selain itu, berdasarkan tingkat pertumbuhan, $R$. mucronata dapat ditemukan baik pada tingkat semai sampai pohon. Hal ini menunjukkan bahwa jenis tersebut memiliki kemampuan beradaptasi yang paling baik dan memiliki kemampuan regenerasi yang baik (Tabel 6). Berdasarkan hasil perhitungan Indeks Nilai Penting, kelimpahan jenis mangrove pada tiga stasiun mengalami sedikit perubahan. Pada tingkat semai dan pancang didominasi oleh $R$. mucronata tetapi pada tingkat pohon di dominasi oleh jenis A. alba (Tabel 7).

Rhizophora mucronata merupakan jenis mangrove sejati yang memiliki persebaran paling luas dan paling toleran terhadap substrat yang lebih keras dan pasir (Noor et al. 2006). Jenis tersebut dapat tumbuh optimal pada areal yang tergenang dalam dan tanah yang kaya akan humus. Kawasan mangrove Desa Mojo merupakan areal yang tergenang dalam sehingga merupakan habitat yang sesuai bagi pertumbuhan $R$. mucronata. Perbungaan $R$. mucronata terjadi sepanjang tahun tetapi anakan yang tumbuh seringkali dimakan oleh kepiting sehingga proses regenerasinya menjadi terhambat. Selain itu, arus gelombang laut yang cukup tinggi dapat menghempaskan benih yang jatuh dari pohon induknya sehingga menyebabkan calon anakan tidak dapat tumbuh dengan baik.

Pada stasiun 1 dan 2 ditemukan jenis A. ilicifolius sedangkan pada stasiun 3 tidak ditemukan jenis tersebut. Jenis tanaman tersebut bukan merupakan jenis yang sengaja ditanam, tetapi dapat tumbuh secara alami. Acanthus ilicifolius merupakan jenis mangrove sejati yang memiliki kekhasan sebagai

Tabel 6. Spesies mangrove pada tiap plot pengamatan Table 6. Mangrove species on each observation plots

\begin{tabular}{|c|c|c|c|c|c|}
\hline \multirow{2}{*}{$\begin{array}{c}\text { Stasiun } \\
\text { Pengamatan }\end{array}$} & \multirow{2}{*}{ No } & \multirow{2}{*}{ Spesies } & \multicolumn{3}{|c|}{ Tingkat Pertumbuhan } \\
\hline & & & Semai & Pancang & Pohon \\
\hline \multirow{5}{*}{ 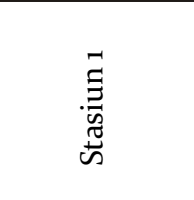 } & 1 & Acanthus ilicifolius L. & $\sqrt{ }$ & & \\
\hline & 2 & Avicennia alba Blume & & $\sqrt{ }$ & $\sqrt{ }$ \\
\hline & 3 & Avicennia marina (Forsk.) Vierh. & $\sqrt{ }$ & $\sqrt{ }$ & $\sqrt{ }$ \\
\hline & 4 & Rhizophora apiculata Blume & & $\sqrt{ }$ & \\
\hline & 5 & Rhizophora mucronata Lam. & $\sqrt{ }$ & $\sqrt{ }$ & $\sqrt{ }$ \\
\hline \multirow{5}{*}{ 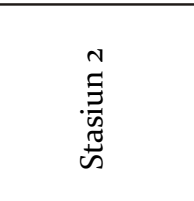 } & 1 & Acanthus ilicifolius L. & $\sqrt{ }$ & & \\
\hline & 2 & Avicennia alba Blume & & $\sqrt{ }$ & $\sqrt{ }$ \\
\hline & 3 & Avicennia marina & & $\sqrt{ }$ & $\sqrt{ }$ \\
\hline & 4 & Rhizophora mucronata & $\sqrt{ }$ & $\sqrt{ }$ & $\sqrt{ }$ \\
\hline & 5 & Sonneratia alba Sm. & $\sqrt{ }$ & & \\
\hline \multirow{3}{*}{ 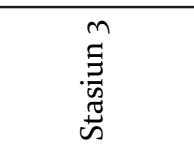 } & 1 & Avicennia alba Blume & & $\sqrt{ }$ & $\sqrt{ }$ \\
\hline & 2 & Avicennia marina (Forsk.) Vierh. & & $\sqrt{ }$ & $\sqrt{ }$ \\
\hline & 3 & Rhizophora mucronata Lam. & $\sqrt{ }$ & $\checkmark$ & $\checkmark$ \\
\hline
\end{tabular}


Tabel 7. Jenis tanaman yang memiliki indeks nilai penting tertinggi

Table 7. Plant species with highest important value index

\begin{tabular}{|c|c|c|c|c|c|c|}
\hline $\begin{array}{c}\text { Stasiun } \\
\text { Pengamatan }\end{array}$ & $\begin{array}{c}\text { Tingkat } \\
\text { Pertumbuhan }\end{array}$ & Jenis & KR (\%) & FR (\%) & DR (\%) & INP \\
\hline \multirow{3}{*}{1} & Semai & Rhizophora mucronata & 81,08 & 71,43 & - & 152,51 \\
\hline & Pancang & Rhizophora mucronata & 86,63 & 52,17 & 72,00 & 210,80 \\
\hline & Pohon & Avicennia alba & 68,00 & 57,89 & 69,30 & 195,19 \\
\hline \multirow{3}{*}{2} & Semai & Rhizophora mucronata & 54,55 & 63,64 & - & 118,18 \\
\hline & Pancang & Rhizophora mucronata & 89,35 & 57,14 & 71,34 & 217,83 \\
\hline & Pohon & Avicennia alba & 77,61 & 60,00 & 65,38 & 202,99 \\
\hline \multirow{3}{*}{3} & Semai & Rhizophora mucronata & 100 & 100 & - & 200 \\
\hline & Pancang & Rhizophora mucronata & 94,86 & 66,67 & 92,41 & 253,93 \\
\hline & Pohon & Avicennia alba & 48,24 & 45.83 & 47,80 & 141,87 \\
\hline
\end{tabular}

herba yang tumbuh rendah dan kuat serta memiliki kemampuan untuk menyebar secara vegetatif karena perakarannya yang berasal dari batang horizontal sehingga membentuk bagian yang besar dan kokoh (Noor et al. 2006). Penyebaran jenis tersebut di kawasan mangrove Mojo berada pada zona distal.

Jenis $S$. alba hanya ditemukan pada stasiun 2 dan hanya pada tingkat semai. Hal ini dimungkinkan jenis tersebut berasal dari lokasi lain yang kemudian terbawa oleh arus gelombang dan berhenti pada kawasan tersebut serta mampu tumbuh dan berkembang di kawasan stasiun 2. Menurut Noor et al. (2006), S. alba merupakan jenis pionir dan sering ditemukan di lokasi pesisir yang terlindung dari hempasan gelombang, di muara, dan sekitar pulau-pulau lepas pantai. Hal ini sesuai dengan kondisi di lapangan dimana jenis tersebut ditemukan pada zona distal yang terlindung dari hempasan gelombang laut.

Keanekaragaman jenis (indeks diversitas) mangrove baik pada tingkat semai, pancang, maupun pohon termasuk dalam kategori rendah karena memiliki nilai Indeks Diversitas Shannon ( $\left.H^{\prime}\right)$ kurang dari 1,5 (Gambar 5). Pada kawasan mangrove Desa Mojo, jumlah jenis yang ditemukan hanya sebanyak enam jenis dan terdapat satu jenis yang mendominasi pada setiap tingkat pertumbuhan yaitu $R$. mucronata (tingkat semai dan pancang) dan A. alba (tingkat pohon) sehingga indeks diversitasnya menjadi rendah. Hal ini sesuai dengan pernyataan Indriyanto (2006), bahwa suatu komunitas dikatakan memiliki keanekaragaman jenis rendah jika komunitas tersebut disusun oleh sedikit jenis dan hanya ada sedikit jenis yang mendominasi.

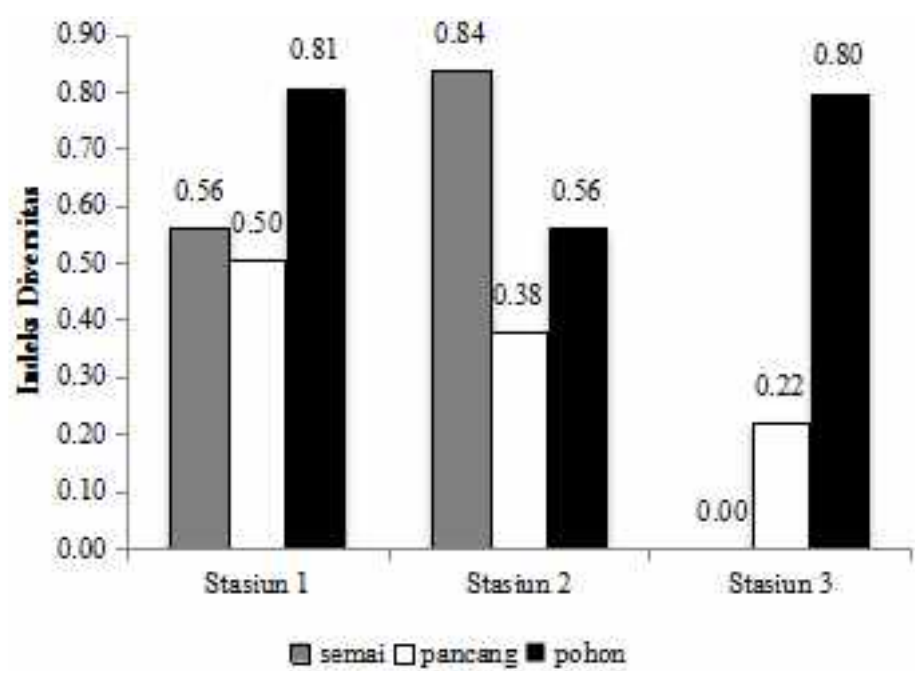

Gambar 5. Indeks diversitas pada tiap tingkat pertumbuhan Figure 5. Diversity index of life form 
Berdasarkan hasil PCA yang disajikan pada Tabel 8 dan 9 menunjukkan bahwa pengelompokan jenis berdasarkan lima karakteristik habitat cukup dilakukan dengan menggunakan faktor 1 dan 2. Kedua faktor tersebut dapat menjelaskan sebesar 99,31\% dari variasi total. Faktor utama lainnya tidak digunakan dalam klasifikasi karena mempunyai kemampuan yang cukup rendah dalam menerangkan variasi total atau lebih rendah dari kontribusi rata-rata setiap variabel terhadap varian total. Hasil PCA dari lima variabel karakteristik habitat menunjukkan bahwa seluruh variabel memiliki pengaruh nyata terhadap variabel baru. Pada tabel eigenvalues dan tabel factor loadings menunjukkan bahwa faktor utama $1\left(\mathrm{~F}_{1}\right)$ merepresentasikan sekitar 82,16\% dari keragaman data dengan variabel penciri utamanya $\mathrm{pH}(0,9852)$, oksigen terlarut $(-0,9686)$, salinitas $(0,8898)$, dan ketebalan lumpur $(0,9886)$ sedangkan pada faktor utama 2 (F2) merepresentasikan sekitar 17,15\% dari keragaman data dengan variabel pencirinya suhu dengan nilai factor loadings sebesar 0,7522.

Pada F1, variabel oksigen terlarut berkorelasi negatif, dimana dengan meningkatnya $\mathrm{pH}$, salinitas, dan ketebalan lumpur, di sisi lain justru dapat menurunkan oksigen terlarut dalam perairan. Peningkatan $\mathrm{pH}$ dapat meningkatkan aktivitas dekomposer. Untuk dapat hidup, dekomposer membutuhkan oksigen untuk respirasi sehingga peningkatan aktivitas dekomposer dapat meningkatkan jumlah konsumsi oksigen terlarut, akibatnya kandungan oksigen terlarut di perairan dapat menjadi lebih rendah.

Perubahan salinitas secara spasial tidak berpengaruh langsung terhadap vegetasi tetapi dapat membahayakan biota lain yang berasosiasi dengan vegetasi (Poedjirahajoe 2007). Peningkatan salinitas dapat menyebabkan kematian bagi biota termasuk fitoplankton sebagai penghasil oksigen, akibatnya kandungan oksigen terlarut di perairan dapat mengalami penurunan. Peningkatan ketebalan lumpur dapat menyebabkan penurunan oksigen terlarut. Hal ini dapat terjadi karena penambahan substrat berasal dari arus pasang yang membawa substrat lumpur sehingga seringkali menyebabkan peningkatan kekeruhan air. Air yang keruh akan menyulitkan penetrasi cahaya masuk ke permukaan air sehingga mengakibatkan fitoplankton tidak dapat berfotosintesis secara optimal, akibatnya jumlah oksigen terlarut yang dihasilkan menjadi lebih rendah.

Setelah didapatkan nilai komponen utama, kemudian dilakukan analisis lanjutan menggunakan analisis kelompok (cluster analysis) dengan metode K-Means. Berdasarkan dua faktor utama yang diperoleh dari analisis komponen utama didapatkan tiga

Tabel 8. Eigenvalue faktor hasil PCA terhadap variabel karakteristik habitat

Table 8. Results of eigenvalues PCA factors to variables of habitat characteristics

\begin{tabular}{lrcccr}
\hline & \multicolumn{1}{c}{$\mathrm{F}_{1}$} & $\mathrm{~F}_{2}$ & $\mathrm{~F}_{3}$ & $\mathrm{~F}_{4}$ & \multicolumn{1}{c}{$\mathrm{F}_{5}$} \\
\hline Eigenvalue & 4,1081 & 0,8576 & 0,0288 & $\mathbf{0 , 0 0 5 6}$ & 0,0000 \\
Variability (\%) & 82,1616 & 17,1515 & 0,5753 & 0,1114 & 0,0001 \\
Cumulative \% & 82,1616 & 99,3131 & 99,8885 & 99,9999 & 100, oooo \\
\hline
\end{tabular}

Tabel 9. Loading factor pada tiap faktor fisik dan kimia habitat

Table 9. Loading factor of physical and chemical habitat factors

\begin{tabular}{lccccc}
\hline \multicolumn{1}{c}{ Variabel } & $\mathrm{F} 1$ & $\mathrm{~F} 2$ & $\mathrm{~F}_{3}$ & $\mathrm{~F} 4$ & $\mathrm{~F}_{5}$ \\
\hline $\mathrm{pH}$ & 0,9852 & $-0,1685$ & $\mathrm{o}, 0110$ & $-0,0278$ & 0,0019 \\
Oksigen terlarut & $-0,9686$ & $-0,2064$ & 0,1386 & 0,0058 & 0,0005 \\
Salinitas & 0,8898 & $-0,4528$ & 0,0103 & 0,0560 & $-0,0001$ \\
Suhu & 0,6559 & 0,7522 & 0,0595 & 0,0236 & 0,0003 \\
Tebal lumpur & 0.9886 & $-0,1258$ & 0,0761 & $-0,0327$ & $-0,0015$ \\
\hline
\end{tabular}


kelompok besar dengan karakteristik habitat seperti tersaji pada Tabel 10. Dari tabel tersebut dapat diartikan bahwa cluster 1 dicirikan dengan $\mathrm{pH}$, salinitas, dan tebal lumpur yang rendah serta suhu yang sedang dan oksigen terlarut yang tinggi. Cluster 2 dengan suhu yang rendah serta tebal lumpur, $\mathrm{pH}$, oksigen terlarut, dan salinitas yang sedang. Cluster 3 dengan $\mathrm{pH}$, salinitas, suhu, dan tebal lumpur yang tinggi serta oksigen terlarut yang rendah.

Tahapan selanjutnya yaitu dengan melihat perbedaan variabel pada cluster yang terbentuk, dalam hal ini dapat dilihat dari nilai $\mathrm{F}$ dan nilai probabilitas (sig) masing-masing variabel (Tabel 11). Berdasarkan tabel tersebut, seluruh variabel kecuali oksigen terlarut (DO) menunjukkan adanya perbedaan di antara jenis mangrove pada ketiga cluster yang terbentuk. Namun, tebal lumpur adalah variabel yang paling menunjukkan adanya perbedaan di antara jenis mangrove pada ketiga cluster yang terbentuk. Langkah selanjutnya adalah mengetahui jumlah anggota masing-masing cluster yang terbentuk, yaitu dengan melihat output pada Tabel 12.

Jenis mangrove yang masuk dalam cluster 1 yaitu R. mucronata dan S.alba. Berdasarkan hasil PCA yang disajikan pada Gambar 6 menunjukkan bahwa sebaran kedua jenis tersebut dipengaruhi oleh suhu dan kandungan oksigen terlarut. Jenis mangrove yang masuk dalam cluster 2 yaitu A. ilicifolius, A. alba, dan $R$. apiculata. Berdasarkan hasil PCA yang disajikan pada Gambar 6 menunjukkan bahwa sebaran kedua jenis tersebut dipengaruhi oleh kandungan oksigen terlarut, salinitas, $\mathrm{pH}$, dan tebal lumpur. Jenis mangrove yang masuk dalam cluster 3 adalah Avicennia marina. Berdasarkan hasil PCA yang disajikan pada Gambar 6 menunjukkan bahwa sebaran jenis tersebut dipengaruhi oleh salinitas,

Tabel 1o. Hasil akhir cluster centers

Table 1o. Output of final cluster centers

\begin{tabular}{lccr}
\hline \multirow{2}{*}{ Z-score } & \multicolumn{3}{c}{ Cluster } \\
\cline { 2 - 4 } & \multicolumn{1}{c}{$\mathbf{1}$} & $\mathbf{2}$ & \multicolumn{1}{c}{3} \\
\hline Zscore (pH) & $-0,9781$ & 0,1036 & 1,6456 \\
Zscore (Oksigen terlarut) & 0,6012 & 0,1988 & $-1,7987$ \\
Zscore (Salinitas) & $-1,1757$ & 0,3674 & 1,2492 \\
Zscore (Suhu) & 0,1457 & $-0,6848$ & 1,7630 \\
Zscore (Tebal lumpur) & $-0,9401$ & 0,0501 & 1,7298 \\
\hline
\end{tabular}

Tabel 11. Hasil pengelompokan Anova

Table 11. Result of Anova grouping

\begin{tabular}{lcccccc}
\hline \multirow{2}{*}{ Variabel } & \multicolumn{2}{c}{ Cluster } & \multicolumn{2}{c}{ Error } & & F \\
\cline { 2 - 6 } & Mean Square & df & Mean Square & df & & \\
\hline Zscore (pH) & 2,327 & 2 & 0,115 & 3 & 20,150 & 0,018 \\
Zscore (DO) & 2,038 & 2 & 0,308 & 3 & 6,624 & 0,079 \\
Zscore (Salinitas) & 2,365 & 2 & 0,090 & 3 & 26,280 & 0,013 \\
Zscore (Suhu) & 2,279 & 2 & 0,147 & 3 & 15,456 & 0,026 \\
Zscore (Tebal lumpur) & 2,384 & 2 & 0,078 & 3 & 30,711 & 0,010 \\
\hline
\end{tabular}

Tabel 12. Anggota tiap cluster

Table 12. Member of each cluster

\begin{tabular}{llc}
\hline \multicolumn{1}{c}{ Cluster 1 } & \multicolumn{1}{c}{ Cluster 2 } & \multicolumn{1}{c}{ Cluster 3 } \\
\hline 1. Rhizophora mucronata & 1. Acanthus ilicifolius & 1. Avicennia marina \\
2. Sonneratia alba & 2. Avicennia alba & \\
& 3. Rhizophora apiculata & \\
\hline
\end{tabular}




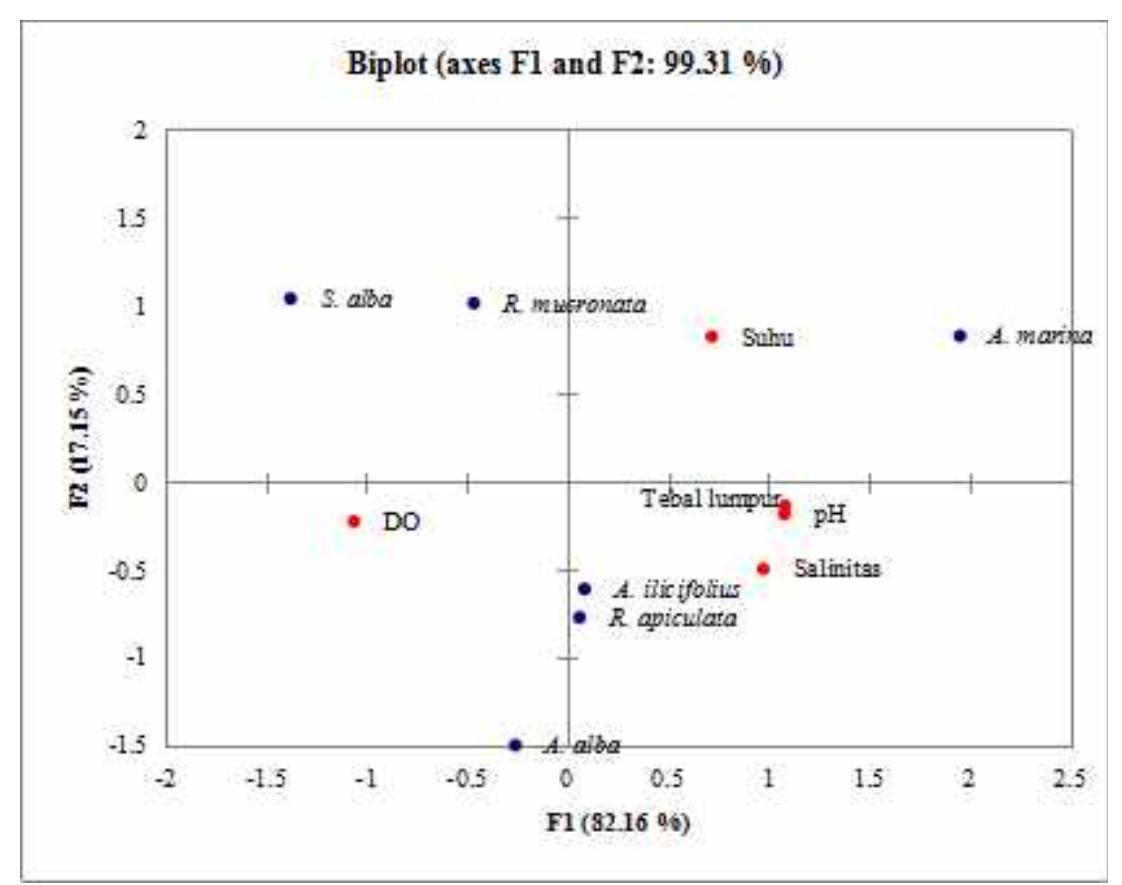

Gambar 6. Sebaran spasial jenis mangrove berdasarkan karakteristik habitat

Figure 6. Spatial distribution of mangrove species based on habitat characteristics

suhu, $\mathrm{pH}$, dan tebal lumpur. Avicennia merupakan marga yang memiliki kemampuan toleransi terhadap kisaran salinitas yang luas dibandingkan dengan marga lainnya. Jenis tersebut mampu tumbuh dengan baik pada salinitas yang mendekati tawar sampai dengan 90\%o tetapi pada salinitas yang ekstrim, pohon tumbuh kerdil dan kemampuan menghasilkan buah hilang (Noor et al. 2006).

\section{Kesimpulan}

Sebaran spasial karakteristik faktor habitat mangrove pada setiap stasiun pengamatan di Pantai Utara Pemalang membentuk tiga cluster dengan karakteristik habitat yang berbeda. Cluster 1 terdiri dari $R$. mucronata dan S. alba dengan karakteristik habitat berupa $\mathrm{pH}$, salinitas, dan tebal lumpur yang rendah, suhu yang sedang, dan oksigen terlarut yang tinggi. Cluster 2 tersusun oleh Acanthus ilicifolius, Avicennia alba, dan R. apiculata dengan karakteristik habitat berupa suhu yang rendah serta tebal lumpur, $\mathrm{pH}$, oksigen terlarut, dan salinitas yang sedang. Cluster 3 berupa Avicennia marina dengan karakteristik habitat berupa $\mathrm{pH}$, salinitas, suhu, dan tebal lumpur yang tinggi serta oksigen terlarut yang rendah.

\section{Daftar Pustaka}

Alongi DM. 2009. The energetics of mangrove forests. Springer, Australia.

Bengen DG. 200o. Teknik pengambilan contoh dan analisis data biofisik sumberdaya pesisir. Hlm. 86. Pusat Kajian Sumberdaya Pesisir dan Lautan Institut Pertanian Bogor, Bogor.

Cahyani LE. 2001. Kualitas fisik, kimia, dan biologi perairan Sungai Donan di sekitar buangan Holding Basin Industri pengolahan minyak Pertamina Cilacap Jawa Tengah. Jurusan Kimia Fakultas Matematika dan Ilmu Pengetahuan Alam, Institut Pertanian, Bogor.

Darmawan A. 2002. Peranan rehabilitasi mangrove dalam mengakumulasi substrat lumpur di Pantai Brebes. Fakultas Kehutanan, Universitas Gadjah Mada, Yogyakarta.

Effendi H. 2003. Telaah kualitas air bagi pengelolaan sumber daya dan lingkungan perairan. Kanisius, Yogyakarta.

Hogarth PJ. 2007. The biology of mangroves and seagrasses Second edition. Oxford University Press, New York.

Indriyanto. 2006. Ekologi hutan. Bumi Aksara, Jakarta.

Koch EW. 2001. Beyond light: Physical, biological, and geochemical parameters as possible submersed aquatic vegetation habitat requirements. Estuaries 24:1-17.

Ludwiq JA, Reynolds JF. 1988. Statistical ecology a primer on methods and computing. John Wiley \& Sons, New York.

Noor RYM, Khazali INN, Suryodiputro. 2006. Panduan pengenalan mangrove di Indonesia. PKA/WI-IP, Bogor. 
Poedjirahajoe E. 2006. Klasifikasi lahan potensial untuk rehabilitasi mangrove di Pantai Utara Jawa Tengah (Rehabilitasi mangrove menggunakan jenis Rhizophora mucronata). Disertasi (Tidak dipublikasikan). Ilmu Kehutanan, Program Pascasarjana, Universitas Gadjah Mada, Yogyakarta.

Poedjirahajoe E. 2007. Pengelompokan mangrove berdasarkan faktor habitat di Pantai Utara Jawa Tengah. Laporan DPP Fakultas Kehutanan, Universitas Gadjah Mada, Yogyakarta.

Poedjirahajoe E. 2010. Kajian ekosistem mangrove untuk estimasi kandungan tanin di kawasan rehabilitasi Pantai Utara Jawa Tengah. Fakultas Kehutanan, Universitas Gadjah Mada, Yogyakarta.

Septiarusli IE. 2010. Ekosistem Mangrove di Jawa Barat. Dalam: www.marine-ecology.wordpress.com (diakses Mei 2015).

Soerianegara I, Indrawan. 1982. Ekologi hutan Indonesia. Departemen Manajemen Hutan, Fakultas Kehutanan, Institut Pertanian Bogor, Bogor. 